\title{
Values and leadership expectations of future managers: Theoretical basis and methodological approach of the GLOBE Student project ${ }^{2}$
}

\author{
Tomaž Čater, Rainhart Lang, Erna Szabo*
}

This article introduces the joint research project titled "GLOBE Student" with its focus on seven Central and Eastern European countries at its current stage. The project's overall aim is to investigate cultural ideals and practices as well as leadership prototypes of future managers, based on the assumption that today's students will likely form the future management in business organisations. In this article we describe the theoretical background of our project and develop a model for the analysis and interpretation of the data collected. We critically evaluate the original project's theoretical concepts and also discuss their appropriateness and shortcomings for the analysis and explanation of students' leadership prototypes.

Dieser Artikel stellt das gemeinsame Forschungsprojekt "GLOBE Student” vor, welches sieben zentral- und osteuropäische Länder zum Inhalt hat. Ziel ist die Untersuchung kulturgeprägter Ideale und Praktiken sowie Führungsprototypen zukünftiger Führungskräfte, unter der Annahme, dass die heutigen Studenten die zukünftigen Führungskräfte in Organisationen darstellen. In diesem Artikel beschreiben wir den theoretischen Hintergrund unseres Projektes und entwickeln ein Modell zur Datenanalyse und -interpretation. Wir unterziehen die dem Ursprungsprojekt zugrundeliegende theoretische Konzeption einer kritischen Würdigung und diskutieren deren Eignung und Schwächen zur Analyse und Erklärung studentischer Führungsprototypen.

Key words: GLOBE, CEE countries, students, intercultural differences, theoretical basis, role models (J24, M14)

\footnotetext{
${ }^{2}$ We would like to thank the authors of this special issue for their patience, and the reviewers for their valuable recommendations.

* Tomaž Čater, Ph.D., Associate Professor, Faculty of Economics, University of Ljubljana, Slovenia. Main research interests: Corporate strategy, business strategy, environmental strategy, competitive advantage, intellectual capital. Corresponding address: tomaz.cater@ef.uni-lj.si

Rainhart Lang, Full Professor, Department of Economics \& Business Administration, Chemnitz University of Technology, Germany. Main research interests: Leadership theories and cross cultural aspects of management and leadership, organisational change and transformation, managerial professions.

Erna Szabo, Associate Professor, Department of International Management, Johannes Kepler University Linz, Austria. Main research interests: Participative and ethical leadership, cultural intelligence, crossvergence, erosion of trust.
} 


\section{Introduction}

GLOBE, the Global Leadership and Organisational Behaviour Effectiveness Research Program, was initiated by Robert J. House of the Wharton School at the University of Pennsylvania together with researchers from the University of Maryland in the early 1990s. This initial project formed the basis for developing a worldwide GLOBE community, which consisted of researchers from 62 countries by the end of the 1990s. GLOBE's main objective concerned the extent to which cultural practices and values, as well as perceptions of effective business leadership, are universal vs. specific to a country or a country cluster (House 2004: 3). First results showed that universal as well as culturally contingent leadership attributes exist (Den Hartog et al. 1999). This means that the perception of what constitutes good leadership is partly universal and partly dependent on the specific cultural context. This finding enabled GLOBE researchers to form implicit leadership theories in several cultural environments (House et al. 2004; Chhokar et al. 2007; Dorfman et al. 2012). Regarding Europe, the results revealed similarities as well as differences in leadership expectations. Similarities were found for example between North European and Germanic cultures (Dorfman et al. 2004). With respect to the expectation of autonomous leadership behaviour, Germanic and East European cultures revealed some similarities (Lang et al. 2005), both regions can be found at the top of GLOBE regional expectations toward autonomous behaviour of leaders (e.g. House 2002: 57). In contrast, significant differences were also found within Europe, for example, between Germany and Austria on the one hand and Central and Eastern European (CEE) countries (such as Estonia and Romania) on the other hand, in particular for perceived leadership. Furthermore, differences within the CEE region, i.e. between the cultures of different CEE countries, also emerged (Lang et al. 2005; Steyrer et al. 2006).

The results of the GLOBE project are based on a data set of middle managers in three industries, namely financial services, food processing, and telecommunications. On the one hand, there is a benefit to using middle managers, because they experience leadership as recipients while at the same time they are leaders themselves (Javidan et al. 2006). On the other hand, by relying on middle managers exclusively, moreover from a limited number of industries, GLOBE's data set on societal cultures as well as on leadership attributes can be considered limited. This raises questions regarding the generalisation of the results to the overall countries/economies. Follow-up studies of other social groups may therefore be helpful to broaden the empirical basis on cultural similarities and differences ${ }^{3}$.

\footnotetext{
${ }^{3}$ Hofstede (1991: 66, 306ff) gave examples of strong differences between various groups of employees with regard to some cultural items, while Lindert (1996: 94-104) reported similar findings for CEE countries and Germany.
} 
Our research interest is similar to the main research objective of the GLOBE project with one important difference. Namely, the focus is not on current middle managers but on future middle managers, i.e. today's students. Our research questions therefore focus on what we can expect in the future: How do future managers perceive today's cultural practices and cultural values? What will their future leadership style possibly look like and how will it evolve?

To shed light on these questions, we started the "GLOBE Student" research project, which focuses on (potential) future managers and their perceptions of societal culture dimensions and leadership styles. We made the assumption that future middle managers will primarily be recruited from the pool of today's university students, mainly in the fields of business economics and engineering. Focusing on this particular subset of students seems justified by the observation that the primary educational background of today's managers is exactly in these fields.

Studying the expectations of future middle managers is important and relevant because it enables us to better understand how they will co-operate with the current middle managers, the likely future top managers. Such an investigation may be of even stronger interest in CEE countries, for which authors (e.g. Pohlmann/Gergs 1996; Clark/Soulsby 1999; Edwards/Lawrence 2000; Steger/Winkler 2003; Lang et al. 2005, 2008) often report about the so-called "stickiness" of traditional or conservative leadership styles. Our research interest thus concerns the question, whether this stickiness will likely change with a new generation of managers.

The GLOBE Student project was initiated in 2008 and has been organised as a relatively permanent project. Initially it attracted researchers from five CEE countries, specifically from the Czech Republic, Germany, Romania, Slovakia and Slovenia. In 2010 researchers from two additional CEE countries, namely Austria and Poland, joined the project, thus enabling the creation of a large database gathered from students studying in these seven countries ${ }^{4}$. It is our goal to further expand the pool of CEE countries in the near future, with some colleagues currently already collecting data in their respective countries.

The purpose of this introductory article of the JEEMS special issue about the GLOBE Student project is to provide readers with the project's theoretical and methodological background, thus also facilitating the understanding of the remaining articles in this special issue. The article is structured into five main

\footnotetext{
${ }^{4}$ The project is co-ordinated by R. Lang (Chemnitz University of Technology, Germany). The other international research participants currently are E. Szabo (Johannes Kepler University Linz, Austria), Z. Konečná (Brno University of Technology, Czech Republic), P. Skálová (University of West Bohemia, Pilsen, Czech Republic), R. Krzykała-Schaefer (Poznań School of Banking, Poland), D. Catana and G.A. Catana (Technical University of Cluj-Napoca, Romania), A. Lašáková and A. Remišová (Comenius University Bratislava, Slovakia), and T. Čater and D. Pučko (University of Ljubljana, Slovenia). This group of researchers regularly meets at the Eastforum conference, bi-yearly organised by the Chemnitz University of Technology.
} 
parts. Following the introduction, the second part offers a review of the relevant literature on cultural dimensions and managerial leadership styles, while the third part discusses methodological issues of the GLOBE Student project. The final part of the article describes limitations of the study and provides a conclusion.

\section{Theoretical background on cultural dimensions and leadership}

The primary source for the theoretical concepts used in our research is the original GLOBE project, with some of the GLOBE-based concepts being adapted by the GLOBE Student research group. The adaptation is based on the fact that we are dealing with the future generation of managers, who are currently still in their "formative years". Students' value sets and perceptions, regarding for example what managerial work entails, are likely still under a significant influence by various social factors, ranging from the earlier socialisation in family and school to the current field of study, as well as social contacts in peer groups, mass media and new technology.

In the following paragraphs we briefly define two sets of constructs as used in our study. The first set of constructs concerns cultural dimensions, which we discuss in two ways, in other words as cultural practices (measured as the students' perceptions of the societal culture "as it is") and as cultural values (measured as the students' ideals concerning the societal culture "as it should be”). The second set of constructs concerns expected leadership styles.

\section{Cultural dimensions}

Anthropologists do not agree on the precise meaning of culture (Schneider/Barsoux 2003: 21). Some definitions include anything from law and religion to art, while others concentrate on specific "value orientations". The anthropologist Margaret Mead proposed to understand culture as "shared patterns of behaviour", while Claude Levi-Strauss and Clifford Geertz defined it as "systems of shared meaning or understanding" (Schneider/Barsoux 2003: 22). The management scholar Edgar H. Schein (2010: 18) defines culture as, "a pattern of shared basic assumptions learned by a group as it solved its problems of external adaptation and internal integration, which has worked well enough to be considered valid and, therefore, to be taught to new members as the correct way to perceive, think, and feel in relation to those problems."

Since our study builds on the original GLOBE research instruments, we use GLOBE's definition, which defines culture as "shared motives, values, beliefs, identities, and interpretations or meanings of significant events that result from common experience of members of collectives that are transmitted across generations” (House/Javidan 2004: 15). While the psychological attributes of the above definition can be applied to both societal and organisational levels of analysis (as was the case in the GLOBE research), our study discusses only the 
societal level because of our focus on a population without substantial fulltime work experience yet, namely students.

A number of social scientists have tried to identify the dimensions that constitute a societal culture. In fact, all models of culture reviewed by Taras, Rowney and Steel (2009) were found to be multidimensional. The cultural dimensions probably most frequently referred to are the ones proposed by Hofstede (1980, 2001), specifically Uncertainty Avoidance, Power Distance, Individualism, Masculinity, and Long-term Orientation. The GLOBE research followed in Hofstede's footsteps yet also searched for additional dimensions and adopted a "deliberate theory-driven design of measurement scales" (Smith 2006: 920). After statistic pre-tests the following nine cultural dimensions ${ }^{5}$ were elicited (Javidan et al. 2004; Dorfman et al. 2012):

(1) Uncertainty Avoidance: The extent to which members of a society strive to avoid uncertainty by relying on established social norms, rituals and bureaucratic practices.

(2)Power Distance: The degree to which members of a society expect and agree that power should be stratified and concentrated at the top.

(3) Institutional Collectivism: The degree to which societal institutional practices encourage and reward collective distribution of resources and collective action.

(4)In-group Collectivism: The degree to which individuals express pride, loyalty and cohesiveness in their families.

(5)Gender Egalitarianism: The degree to which a society minimises gender role differences while promoting gender equality.

(6) Assertiveness: The degree to which individuals in a society are assertive, confrontational and aggressive in social relationships.

(7)Future Orientation: The degree to which individuals in a society engage in future-oriented behaviours such as planning, investing in the future and delaying individual or collective gratification.

(8)Performance Orientation: The degree to which a society encourages and rewards group members for performance improvement and excellence.

(9)Humane Orientation: The degree to which individuals in a society encourage and reward individuals for being fair, altruistic, friendly, generous, caring and kind to others.

\footnotetext{
${ }^{5}$ Although references to prior literature on culture and their respective dimensions, both Hofstede's and GLOBE's scales for cultural dimensions were empirically developed, which means that constructs measured by scales were specified after the scales had been developed (Nunnally/Bernstein 1994), i.e. by employing statistical analyses such as exploratory factor analysis, correlation analysis etc.
} 
Let us briefly explore the theoretical foundation of these cultural dimensions. The first seven dimensions largely build on Hofstede (1980, 2001), although it should be mentioned that these dimensions are also rooted in the work of several other authors. Prior to Hofstede, Uncertainty Avoidance (1) and Power Distance (2) had, for example, been introduced on the organisational level of cultural analysis by Cyert and March (1963) and Mulder (1977), respectively. Similarly, Institutional (3) and In-group (4) Collectivism represent two sub-constructs of Collectivism that was, along with its antonym Individualism, already well known in the psychological, sociological and anthropological literature, before Hofstede (1980) defined it as a societal cultural dimension. Parsons (1949), for example, referred to this construct as Collectivity vs. Self-emphasis, Kluckhohn and Strodtbeck (1961) talked about Collaterality vs. Individualism, and Bakan (1966) used the terms Community vs. Agency. Multidimensionality of the Individualism vs. Collectivism constructs was first suggested by Triandis et al. (1986), whose work is viewed as the basis for GLOBE's In-group Collectivism, while Institutional Collectivism was first studied in its present form by the GLOBE researchers themselves (House/Javidan 2004). The cultural dimensions Gender Egalitarianism (5) and Assertiveness (6) build on Hofstede's (1980) Masculinity/Femininity dimension, but are held separately due to the heavy criticism of Hofstede's original dimension (e.g. by Hoppe 1998; Merritt 2000; House et al. 2004). The dimension Future Orientation (7) is rooted in Kluckhohn and Strodtbeck's (1961) Past, Present and Future Orientation, which focuses on the temporal orientation dominant in a society. Although Hofstede (2001) also talked about Long-term orientation, House/Javidan (2004) argues that GLOBE's Future Orientation is only marginally related to Hofstede's construct. The final two cultural dimensions, Performance Orientation (8) and Humane Orientation (9), are the two dimensions in the GLOBE research that Hofstede did not measure in his studies, not even indirectly. Performance Orientation builds on McClelland's (1961, 1987) findings that people differ in their need for achievement or the need to constantly do better, while the dimension Humane Orientation originates primarily from Kluckhohn and Strodtbeck's (1961) construct labelled "human nature as good vs. bad". The initial publications stemming from the GLOBE project have already triggered a vivid debate in the literature as to the number and content of the dimensions as well as their novelty and/or overlap with Hofstede's work (e.g. Hofstede 2006; Javidan et al. 2006; Smith 2006; Venaik/Brewer 2010; Brewer/Venaik 2011). In the light of the GLOBE findings, earlier conceptualisations of culture have been reconsidered with respect to the impact of culture on leadership (e.g. Dickson et al. 2012).

The GLOBE study focuses on both practices and values as parts of a culture, similar to the anthropologist Redfield (1948: vii), who defined culture as "shared understandings made manifest in act and artifact”. Practices are Redfield's acts, or the way things are done in a culture, while values stand for Redfield's humanmade artifacts representing judgements about the way things should be done in a 
culture (House et al. 2004: xv). Practices represent "what is" or "what are" common behaviours in a society, while values stand for what is expected or hoped for. Research of culture as shared societal practices roots in psychological and behavioural studies, which assume that culture should be studied as it is interpreted by its members (Segall et al. 1998), whereas focus on values grows more out of an anthropological approach, which assumes that culture is largely determined by the shared values of its members (Kluckhohn/Strodtbeck 1961). By focusing on both practices and values, GLOBE's nine cultural dimensions translate into 18 constructs, nine for perceived practices ("as is") and nine for desired values ("as should be").

By incorporating values and practices, GLOBE was the first research initiative among the large-scale comparative studies of the last decades to move beyond a focus on just one perspective of culture. Yet GLOBE's conceptualisation of values and practices has led to scholarly exchange (e.g. in the JIBS Special Issues of 2006 and 2010) and partly harsh critique. For example, Smith (2006: 917) observed that while "most researchers study values in terms of the individual respondent's own preferred end states, [...] GLOBE operationalized values in terms of preferences about the behaviour of others in one's society" (italics in original), and Hofstede (2006, 2010) even wondered what GLOBE had really measured. With regard to practices, GLOBE had intended to elicit a culture's gestalt (Javidan et al. 2006). Yet Hofstede (2006) contested the questionnaire design, Earley (2006) saw an imperfect assessment of actual practices, and McCrae et al. (2008) maintained that some of GLOBE's societal practice scales (e.g. Assertiveness) elicited unsubstantiated stereotypes rather than objective features of a society. Moreover, GLOBE was not able to report a positive relationship between values and practices, as the widely used onion metaphor for culture (Hofstede 1980) would suggest. In contrast, the GLOBE data showed negative correlations for seven of the nine dimensions. Several authors offered explanations for this counterintuitive finding, among them Maseland/van Hoorn's (2009, 2010) thesis related to marginal utility theory (respondents report marginal preferences rather than values) and Taras, Steel and Kirkman's (2010) suggestion of concepts such as anchoring and priming playing a role. Far from agreement, there seems to be a consensus that values may be somehow shaped by existing practices, at least in part. This has to be kept in mind when interpreting the GLOBE results.

Despite a range of existing studies on cultural values or attitudes, to our knowledge only one study has been published so far that uses GLOBE methodology and refers to students (Keating et al. 2002). Data collected in Austria and Ireland suggest a stronger country than cohort/age effect: While no significant differences regarding perception of cultural practices were found among managers and students of the same country, significant differences on several practice dimensions showed between the two country samples. Strong 
convergence between the two countries samples, yet a significant cohort/age effect, was only found for the dimensions Gender Egalitarianism and Power Distance (Keating et al. 2002: 646-647).

Consistent with these findings, there is the general observation that cultural values are relatively stable and do not change quickly (e.g. Schwartz 1996). Resistant to change are in particular such values that are according to Williams (1979: 34), "high in centrality, pervasive, and supported by powerful sanctions and high consensus and supporters of these values hold positions of high prestige and authority." According to the European Values Survey, central values may change when one generation succeeds another (Keating et al. 2002: 637). Additionally, psychologists (e.g. Mead 1998; Helson et al. 2002) make us aware that people's values do change during their life cycle. During the youth period, hedonistic values prevail, while later on the values of power become more important and finally, moral values and self-actualisation take primacy.

\section{Leadership styles ${ }^{6}$ and implicit leadership theories}

Many definitions of leadership have been proposed in the literature, but despite differences among them there seems to be some kind of agreement among authors that leadership is a process, involves influence, occurs within a group context, and involves goal attainment (Northouse 2004). In line with this notion, Kreitner (1989: 511) defines leadership as "a social influence process in which the leader seeks participation of subordinates in an effort to reach organisational objectives". Similarly, the GLOBE study defines leadership as "the ability of an individual to influence, motivate, and enable others to contribute toward the effectiveness and success of the organisations of which they are members" (House/Javidan 2004: 15).

A large number of leadership theories exist in the literature, usually broadly classified into trait theories, style theories and contingency theories (Cole 2004). Trait theories, which focus on the qualities or characteristics expected from effective leaders, received relatively little overall empirical support due to inconsistent sets of traits identified by different researchers. Style theories focus on the effective leader's behaviour at work rather than on his/her characteristics. Leadership styles have mostly been expressed in terms of authoritarian vs. democratic as well as task-oriented vs. people-oriented leadership. Authoritarian vs. democratic leadership is, for example, a focal point of McGregor's (1960) theory X/Y, Likert's (1961) theory of four management systems, and Tannenbaum and Schmidt's (1958) theory of leadership continuum. In contrast, theories such as Reddin's (1970) 3-D theory, Blake and Mouton's (1984) managerial grid, as well as the early studies conducted in the 1950s at the Ohio

\footnotetext{
${ }^{6}$ Lewin defined leadership style as the manner and approach of providing direction, implementing plans and motivating people (Lewin/Llippit/White 1939).
} 
State University, Michigan University and Harvard University, build on taskoriented vs. people-oriented leadership (Cole 2004). Finally, contingency theories, among them Fiedler's (1967) theory of leadership effectiveness, Adair's (1973) functional theory and Hersey and Blanchard's (1977) situational leadership theory, stress that situational variables determine what kind of leadership works best under specific circumstances. While Fiedler argued that the situation should be designed to match the leader, all later models suggest that the leader is able to and should adapt his/her behaviour to the specific context.

During the last twenty years, leadership research has been dominated by neocharismatic leadership concepts like transformational leadership. According to scholars like House (1977), Bass (1985), Conger and Kanungo (1987), Bryman (1992) and House and Shamir (1993), visionary, intellectually-stimulating, follower-inspiring leadership behaviour has been defined as a prototype for successful and outstanding leadership. Moreover, Lord and Maher (1993) point to the importance of perception, categorisation and information processing in shaping such prototypes.

The theory GLOBE builds on, in particular the so-called culturally endorsed implicit theory of leadership, follows more or less the above-mentioned streams of contemporary leadership approaches, but also includes elements of contingency theory. In line with the majority of cross-cultural leadership studies (e.g. Bass 1990; Chemers 1997; Peterson/Hunt 1997; Dorfman 2004), GLOBE’s central proposition is that "the attributes and entities that differentiate a specified culture are predictive of organisational practices and leader attributes and behaviours that are most frequently enacted and most effective in that culture" (House/Javidan 2004: 17). In other words, what constitutes good leadership in a certain cultural context depends (among other things) on the cultural variables in that particular context, including references to leadership prototypes prevailing in the respective culture.

Building on earlier studies of favourable (and less favourable) leadership attributes and behaviours in different cultures, the GLOBE researchers proposed 21 first-order "primary dimensions of leadership", which were then consolidated into six second-order "global leadership dimensions" (Dorfman et al. 2012: 506) ${ }^{7}$ (compare Table 1):

(1)Charismatic/Value-based Leadership: A leader inspires, motivates and expects high performance from others on the basis of firmly held core values.

(2)Team-oriented Leadership: A leader emphasises effective team building and implementation of a common goal among team members.

\footnotetext{
${ }^{7}$ Similar to the cultural dimensions, GLOBE’s leadership dimensions were also derived from empirical data, i.e. constructs were specified after the scales had been developed (Nunnally/Bernstein 1994).
} 
(3) Participative Leadership: A leader involves subordinates in making and implementing decisions.

(4)Humane-oriented Leadership: A leader encourages and rewards individuals for being fair, altruistic, friendly, generous, caring and kind to others. He/she is supportive, considerate, compassionate and generous.

(5)Autonomous Leadership: A leader chooses an independent and individualistic leadership approach.

(6) Self-protective Leadership: A leader focuses on ensuring individual safety and security. He/she is self-centred, status-conscious, procedural and conflict inducing.

It is important to note that the first four dimensions or their components had already been discussed in the literature prior to the GLOBE research, while the GLOBE study was the first to define the last two dimensions. Findings indicate that some of the first- and second-order leadership dimensions are perceived to be good and effective vs. bad and unwanted in all countries and regions, while other factors are more culturally contingent (Brodbeck et al. 2000; Lang et al. 2008). 
Table 1: The consolidation of first-order into second-order leadership dimensions

\begin{tabular}{|c|c|c|c|c|c|c|}
\hline $\begin{array}{l}\text { Global } \\
\text { Leadership } \\
\text { Dimensions } \\
\left(2^{\text {nd }} \text { order }\right)\end{array}$ & $\begin{array}{c}\text { (1) } \\
\text { Charis- } \\
\text { matic/ } \\
\text { Value- } \\
\text { based }\end{array}$ & $\begin{array}{c}(2) \\
\text { Team- } \\
\text { oriented }\end{array}$ & $\begin{array}{c}(3) \\
\text { Partici- } \\
\text { pative }\end{array}$ & $\begin{array}{c}\text { (4) } \\
\text { Humane- } \\
\text { oriented }\end{array}$ & $\begin{array}{c}\text { (5) } \\
\text { Auto- } \\
\text { nomous }\end{array}$ & $\begin{array}{c}\text { (6) } \\
\text { Self- } \\
\text { protective }\end{array}$ \\
\hline \multirow{6}{*}{$\begin{array}{l}\text { Primary } \\
\text { Leadership } \\
\text { Dimensions } \\
\text { (1 } 1^{\text {st }} \text { order) }\end{array}$} & Visionary & $\begin{array}{l}\text { Collabora- } \\
\text { tive team } \\
\text { orientation }\end{array}$ & $\begin{array}{c}\text { Autocratic } \\
\text { (R) }\end{array}$ & Modest & $\begin{array}{c}\text { Auto- } \\
\text { nomous }\end{array}$ & $\begin{array}{l}\text { Self- } \\
\text { centred }\end{array}$ \\
\hline & $\begin{array}{c}\text { Inspira- } \\
\text { tional }\end{array}$ & $\begin{array}{c}\text { Team } \\
\text { integrator }\end{array}$ & $\begin{array}{l}\text { Nonpar- } \\
\text { ticipative } \\
\text { (R) }\end{array}$ & $\begin{array}{c}\text { Humane } \\
\text { orienta- } \\
\text { tion }\end{array}$ & & $\begin{array}{c}\text { Status } \\
\text { conscious- } \\
\text { ness }\end{array}$ \\
\hline & $\begin{array}{c}\text { Self- } \\
\text { sacrifice }\end{array}$ & Diplomatic & & & & $\begin{array}{l}\text { Conflict } \\
\text { inducer }\end{array}$ \\
\hline & Integrity & $\begin{array}{l}\text { Malevolent } \\
\text { (R) }\end{array}$ & & & & Face saver \\
\hline & Decisive & $\begin{array}{l}\text { Administra- } \\
\text { tively } \\
\text { competent }\end{array}$ & & & & Procedural \\
\hline & $\begin{array}{l}\text { Perfor- } \\
\text { mance- } \\
\text { oriented }\end{array}$ & & & & & \\
\hline
\end{tabular}

Source: Hanges/Dickson (2004: 137). Note: R = reverse-scored factor.

In some contrast to GLOBE's conceptualisation of culture (as discussed above), the project's conceptualisation of leadership has received largely positive feedback from the research community. For example, Earley (2006) characterized the leadership part of the GLOBE study as sophisticated crosscultural research, and highlighted the conceptual framework, the constructs' operationalisation and measurement at different levels of analysis, as well as the use of intermediate constructs.

The relationship between cultural dimensions, leadership styles and implicit leadership theories

Many management scholars have attempted to find out whether a direct relationship exists between culture and leadership styles. Quite a few have argued that specific cultural traditions, values, beliefs and norms, which form the cornerstones of a culture, have a direct impact on leadership. Values motivate people and normatively lead their behaviour, interests, thoughts and actions (e.g. Schwartz 1992, 1996; House et al. 2002 for leadership behaviour). 
However, researchers do not completely agree regarding the exact role of values in guiding leadership behaviour. Studies support the assumption that values do motivate behaviours, but that their influence might depend on differences in normative pressures as well as situational pressure on individual's behaviour (Mihelič/Lipičnik 2010: 296). Szabo et al. (2001) classify values and leadership ideals as "far-from-action" concepts (in contrast to "close-to-action" concepts such as intentions) and stress the existence of complex intrapersonal processes (e.g. cognitive information processing concepts, possibly leading to habits over time) as well as the potential influence of situational factors (e.g. time pressure), organisational contingencies (e.g. structure, resources) and external environment factors (e.g. legislation, societal culture), before values and leadership ideals may turn into leadership action.

This may lead to a twofold approach with regard to the relation between culture and leadership: While cultural practices may be viewed as closer to leadership styles, or even leadership styles can be seen as a specific cultural practice, cultural values have to be considered an important factor influencing leadership ideals or expectations. As Dorfman et al. (2012: 510) expressed: "[N]ational culture values do not directly predict CEO leadership behavior. Instead [...] national culture values are antecedent factors which influence leadership expectations." And these culturally endorsed leadership theories (CLTs) show a clear relationship with "actual CEO leadership behavior" so that "CEOs tend to behave in accordance to societies' expectations of their leaders" (Dorfman et al. 2012: 511). With respect to our research interests in CLTs of students, we are mainly focussing on the relation between cultural values and leadership expectations/implicit theories of leadership.

In order to answer our research questions related to the cultural values and leadership ideals of students, we also need to consider the influence of the various places and agents of socialisation from which children and young people learn about the values of their respective culture. This includes their emerging understanding of leadership and their role models for good vs. bad leadership, in other words their implicit leadership theories. The concept of role modelling is consistent with Albert Bandura's social learning theory, which includes the cognitive processes of observational learning, identification and emulation. According to Bandura (1986), role modelling, which presupposes identification with a model and internalisation of his/her values, is learning through vicarious experience, i.e. by observing the respective role model's behaviour and its effects, before imitating this behaviour. Thus, role models serve as a crucial antecedent to leadership development. Hofstede (1991: 32-35) has pointed to family and school as important sources of influence on cultural values, with parents and teachers being important role models. Culture influences the parental value systems transferred to the next generation (Hofstede 1985), but also child-rearing practices. 
Additionally, friends have also been identified as socialising agents (Sahgal/Phatak 2007). In a similar way, peer groups seem to influence the values and role models of young adults, especially in more collectivist cultures, where there is a stronger interdependence between in-group values and individual attitudes (Triandis 2004). Furthermore, socio-demographic factors are relevant in shaping young people's value systems, since for instance gender-role socialisation creates different systems of beliefs, values and expectations regarding the behaviour of females and males (see e.g. Eccles 2007 for motives; Schwartz/Rubel 2005; Grusec/Hastings 2007). Finally, the media may also play an important role by spreading cultural values and role models for behaviour (of leaders) around the world (e.g. Holmberg/Åkerblom 2001; McQuail 2005). During adolescence, which is a crucial phase for occupational preparation and developing one's own set of beliefs and values, the importance of parents and family as socialising agents diminish, thus making adolescents more inclined to use media as sources of socialisation, resulting in an alienation from the core values of their parents (Arnett 1995). Although studies agree that young adults and children are comfortable with media usage due to the increasing presence on a global scale, Choi/La Ferle (2004) showed that patterns of media usage and perception of media may vary between cultures. There is only limited research on the influence of cultural values on the perception of role models in media with regard to their impact on model learning (Giles/Maltby 2004).

In sum, the literature indicates that the above-mentioned socialisation agents vary between cultures, as they have different values and norms, which in turn influence their impact on the socialisation process as a whole. In contrast to these findings, Weaver et al. (2005) and Brown/Treviño (2006) have questioned the relevancy of childhood role models for leadership perceptions of adults as well as for the leadership behaviour, adults display in the workplace.

In our project, we assume that the differences in leadership ideals or implicit leadership theories can be mainly explained by: the influence of a specific cultural environment represented by country of birth and cultural practices, individual cultural values, agents of socialisation like family, school and media, the professionalisation through a specific study program, like engineering or business, and socio-demographic factors like age and gender. Figure 1 shows the overall frame of reference for the project, including more detailed aspects to be analysed. 
Figure 1: General research frame of the GLOBE Student project 3 Method

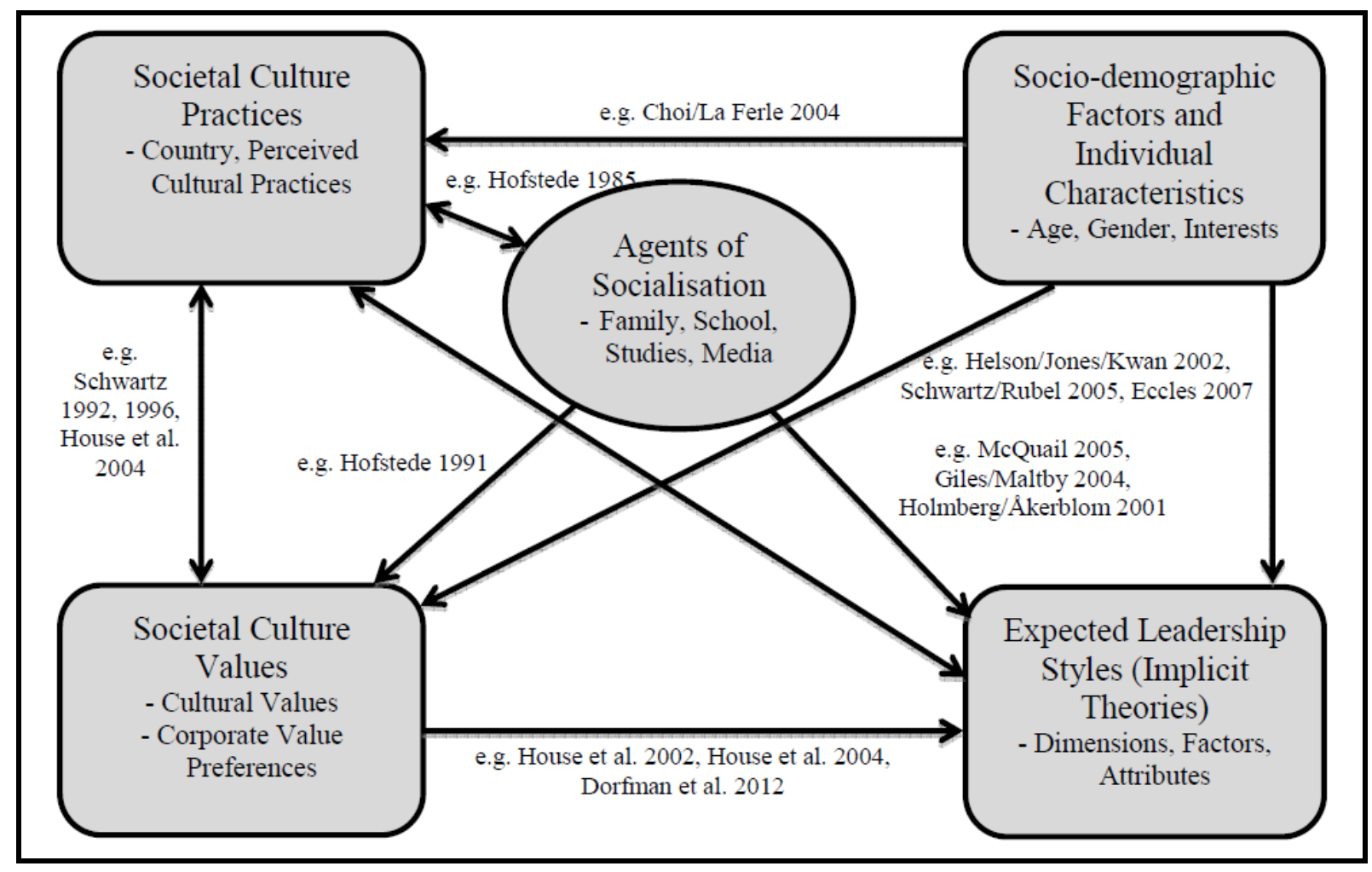

\section{Method}

As described above, our project's objectives are to study and compare leadership expectations and cultural assumptions of students in CEE countries. We used one of the original GLOBE instruments, the GLOBE Beta version questionnaire for national culture and leadership scales (House et al. 2004) and added a couple of items related to our study focus on students. In addition, the GLOBE Student researchers developed specific scales on their own, especially those related to the influence of socialisation agents.

Data were collected in the seven Central and Eastern European countries the members of the GLOBE Student project come from, specifically Austria, Czech Republic, Germany, Poland, Romania, Slovakia and Slovenia. Using a stratified sampling procedure, we collected data from a minimum of 300 business and engineering students in each country. Data collection took place between January 2008 and April 2010. In most cases the questionnaires were distributed to students volunteering to participate in the study before class. They filled them out at home and returned them usually one week later.

The Annex of the special issue (authored by Čater/Lang/Szabo) provides detailed information related to the research instrument, research population, process of data collection, and sample structure. In addition, the authors of the following three articles in this special issue, focusing on societal culture (by Catana/Pučko/Krzykała-Schaefer), leadership ideals (by Lang et al.), and corporate social responsibility (by Remišová/Lašáková/Krzykała-Schaefer), 
describe themselves which particular scales they used for their analyses. According to their specific research questions, they also used specific methods of analysis, mainly descriptive measures, correlation and regression analyses, as well as factor and cluster analyses. While exploring differences between the current and the next generation leaders, these articles also compare some of their GLOBE Student findings with the results of the original GLOBE study.

\section{Study limitations and conclusion}

Limitations of our study can be seen in the theoretical background of the concepts originating from the GLOBE study. As pointed out above, there are weaknesses in the conceptualisation of values and practices, which may result in a challenge to interpret the study findings and compare them with earlier research beyond the context of the original GLOBE study. Furthermore, House and his colleagues assumed a direct link between values and leadership, yet such an assumption may be too simplistic, as pointed out above.

With regard to the unit of analysis, researchers (e.g. McSweeney 2002; Hofstede 2002; Gould/Grein 2009) agree that nation may not be the best unit for comparing cultures. Nonetheless, national samples provide a frequently used and convenient way to study cultural differences, mainly because of their clear boundaries. While national culture does have its unifying aspects, such as shared legislation or institutions, it may not fully overlap with the societal/ethnic culture(s) of its inhabitants. For example, more than one societal or ethnic culture may exist within the boundaries of a nation; likewise ethnic cultures may transcend borders. Furthermore, the argument of a unifying national culture finds its limits, when we consider nations only recently formed, such as Slovenia or Slovakia. In the GLOBE Student project we take the difference between national culture and societal/ethnic culture into account as best as possible (e.g. with regard to respondents' country of origin and mother tongue), similar to the original GLOBE study. However, we also acknowledge that such an approach neglects the whole range of ethnicities living in the countries under study.

As for the GLOBE methodology, we are dealing with the quantification of culture in a functionalist tradition. Such an approach yields limitations, such as the necessary neglect of local meaning and context. Our research instrument turned out to be lengthy and may have overburdened respondents. Questionnaires were administered in the respondents' mother tongue, yet the translation procedure started from different language versions (German and/or English).

Data from seven CEE countries are currently available. The country samples differ somewhat with regard to study programs, gender distribution, and age structure (see Annex of the special issue). The sampling procedure (distributing questionnaires in courses and collecting the completed ones a week later) led to a self-selection process of participation in the study. Furthermore, as countries 
joined the project at different points in time, there was a time lag in sampling between countries.

In conclusion, what can we tell about further prospects and research directions within the GLOBE Student project? Firstly, the current data set calls for an indepth analysis, following verification of the original GLOBE factor structure, checks for possible response biases and the like. Secondly, additional countries may be included as well as follow-up studies conducted. In doing so, we will take suggestions by prominent scholars in the field earnestly. For example, Earley (2006: 928) recommends that, "scholars refocus their attention away from any more of these values surveys and toward developing theories and frameworks for understanding the linkages among culture, perceptions, actions, organizations, structures etc." Leung et al.'s (2005) model, based on the assumption that culture entails more than just cultural dimensions, and consequently treating culture as a multi-level, multi-layer construct may be a good starting point. In a next step and following the calls for moving cultural research outside the functionalist paradigm (e.g. Williamson 2002), we may well broaden our research agenda to complement and challenge our understanding of culture and leadership in the CEE region by employing qualitative studies in the interpretative tradition.

\section{References}

Adair, J. (1973): Action-centered leadership. New York: McGraw-Hill.

Arnett, J.J. (1995): Adolescents' use of media for self-socialization, in: Journal of Youth and Adolescence, 24, 5, 519-533.

Bakan, D. (1966): The dualty of human existence. Chicago: Rand McNally.

Bandura, A. (1986): Social foundations of thought and action. Englewood Cliffs, NJ: Prentice-Hall.

Bass, B.M. (1985): Leadership and performance beyond expectations. New York: Free Press.

Bass, B.M. (1990): Bass \& Stogdill's handbook of leadership: Theory, research, and managerial implications. New York: Free Press.

Blake, R.R./Mouton, J.S. (1984): The new managerial grid III. Houston: Gulf Publishing.

Brewer, P./Venaik, S. (2011): Individualism-collectivism in Hofstede and GLOBE, in: Journal of International Business Studies, 42, 3, 436-445.

Brodbeck, F.C./Frese, M./44 co-authors (2000): Cultural variation of leadership prototypes across 22 European countries, in: Journal of Occupational and Organizational Psychology, 73, 1, 1-29.

Brown M.E./Treviño, L.K. (2006): Role modeling and ethical leadership. Paper presented at the 2006 Academy of Management Annual Meeting. Atlanta, GA.

Bryman, A. (1992): Charisma \& leadership in organizations. London: Sage.

Chemers, M.M. (1997): An integrative theory of leadership. London: Lawrence Erlbaum.

Chhokar, J.S./Brodbeck, F.C./House, R.J. (eds.) (2007): Culture and leadership across the world: The GLOBE book of in-depth studies of 25 societies. Mahwah, NJ: Lawrence Erlbaum Associates. 
Choi, S./La Ferle, C. (2004): Convergence across American and Korean young adults: Socialisation variables indicate the verdict is still out, in: International Journal of Advertising, 23, 4, 479506.

Clark, E./Soulsby, A. (1999): Organisational change in post-communist Europe: Management and transformation in the Czech Republic. London: Routledge.

Cole, G.A. (2004): Management theory and practice. London: Thomson Learning.

Conger, J.A./Kanungo, R. (1987): Toward a behavioral theory of charismatic leadership in organizational settings, in: Academy of Management Review, 12, 4, 637-647.

Cyert, R.M./March, J.G. (1963): A behavioral theory of the firm. Englewood Cliffs: Prentice Hall.

Den Hartog, D.N./House, R.J./Hanges, P.J./Ruiz-Quintanilla, S.A./Dorfman, P.W./169 co-authors (1999): Culture specific and cross-culturally generalizable implicit leadership theories: Are attributes of charismatic/transformational leadership universally endorsed?, in: Leadership Quarterly, 10, 2, 219-256.

Dickson, M.W./Castaño, N./Magomaeva, A./Den Hartog, D.N. (2012): Conceptualizing leadership across cultures, in: Journal of World Business 47, 4, 483-492.

Dorfman, P.W. (2004): International and cross-cultural leadership research, in: Punnett, B.J./Shenkar, O. (eds.): Handbook for international management research ( $2^{\text {nd }}$ ed.). Ann Arbor: University of Michigan Press, 265-355.

Dorfman, P.W./Hanges, P.J./Brodbeck, F.C. (2004): Leadership and cultural variation: The identification of culturally endorsed leadership profiles, in: House, R.J./Hanges, P.J./Javidan, M./Dorfman, P.W./Gupta, V. (eds.): Culture, leadership, and organizations: The GLOBE study of 62 societies. Thousand Oaks: Sage, 669-719.

Dorfman, P.W./Javidan, M./Hanges, P.J./Dastmalchian, A./House, R.J. (2012): GLOBE: A twenty year journey into the intriguing world of culture and leadership, in: Journal of World Business 47, 4, 504-518.

Earley, C.P. (2006): Leading cultural research in the future: A matter of paradigms and taste, in: Journal of International Business Studies, 37, 6, 922-931.

Eccles, J.S. (2007): Families, schools, and developing achievement-related motivations and engagement, in: Grusec, J.E./Hastings, P.D. (eds.): Handbook of socialization: Theory and research. New York: The Gilford Press, 665-691.

Edwards, V./Lawrence, P. (2000): Management in Eastern Europe. Basingstoke: Palgrave.

Fiedler, F. (1967): A theory of leadership effectiveness. New York: McGraw-Hill.

Giles, D.C./Maltby, J. (2004): The role of media figures in adolescent development: Relations between autonomy, attachment, and interest in celebrities, in: Personality and Individual Differences, 36, 4, 813-822.

Gould, S.J./Grein, A.F. (2009): Think glocally, act glocally: A culture-centric comment on Leung, Bhagat, Buchan, Erez and Gibson (2005), in: Journal of International Business Studies, 40, 2, 237-254.

Grusec, J.E./Hastings, P.D. (2007): Handbook of socialization: Theory and research. New York: The Gilford Press. 
Hanges, P.J./Dickson, M.W. (2004): The development and validation of the GLOBE culture and leadership scales, in: House, R.J./Hanges, P.J./Javidan, M./Dorfman, P.W./Gupta, V. (eds.): Culture, leadership, and organizations: The GLOBE study of 62 societies. Thousand Oaks: Sage, 122-151.

Helson, R./Jones, C./Kwan, Y.S.V. (2002): Personality change over 40 years of adulthood: Hierarchical linear modeling analyses of two longitudinal samples, in: Journal of Personality \& Social Psychology, 83, 3, 752-766.

Hersey, P./Blanchard, K.H. (1977): Management of organizational behavior: Utilizing human resources $\left(3^{\text {rd }}\right.$ ed.). New Jersey: Prentice Hall.

Hofstede, G. (1980): Culture's consequences: International differences in work-related values. London: Sage.

Hofstede, G. (1985): The interaction between national and organizational value systems, in: Journal of Management Studies, 22, 4, 347-357.

Hofstede, G. (1991): Cultures and organizations: Software of the mind. Maidenhead: McGraw-Hill.

Hofstede, G. (2001): Culture's consequences: International differences in work-related values $\left(2^{\text {nd }}\right.$ ed.). Thousand Oaks: Sage.

Hofstede, G. (2002): Dimensions do not exist: A reply to Brendan McSweeney, in: Human Relations, $55,11,1355-1361$.

Hofstede, G. (2006): What did GLOBE really measure? Researchers' minds versus respondents' minds, in: Journal of International Business Studies, 37, 6, 882-896.

Hofstede, G. (2010): The GLOBE debate: Back to relevance, in: Journal of International Business Studies, 41, 8, 1339-1346.

Holmberg, I./Åkerblom, S. (2001): The production of outstanding leadership - an analysis of leadership images in the Swedish media, in: Scandinavian Journal of Management 17, 1, 6785.

Hoppe, M.H. (1998): Validating the masculinity/femininity dimension on elites from 19 countries, in: Hofstede, G. (ed.): Masculinity and femininity: The taboo dimension of national cultures. Thousand Oaks: Sage, 29-43.

House, R. J., Javidan, M., Hanges, P. J., Dorfman, P. W. (2002). Understanding Cultures an Implicit Leadership Theories across the Globe: An Introduction to Project GLOBE. In: Journal of World Business, 37: 3-10.

House, R.J. (1977): A 1976 theory of charismatic leadership, in: Hunt, J.G./Larson, L.L. (eds.): Leadership: The cutting edge. Carpondale/Edwardsville: Southern Illinois University Press, 189-205.

House, R.J. (2002): Global leadership and organizational behavior effectiveness research program Results with special respect to Eastern Europe, in: Lang, R. (ed.): Personalmanagement im Transformationsprozess. München/Mering, 43-62.

House, R.J. (2004): Illustrative examples of GLOBE findings, in: House, R.J./Hanges, P.J./Javidan, M./Dorfman, P.W./Gupta, V. (eds.): Culture, leadership, and organizations: The GLOBE study of 62 societies. Thousand Oaks: Sage, 3-8.

House, R.J./Hanges, P.J./Javidan, M./Dorfman, P.W./Gupta, V. (eds.) (2004): Culture, leadership, and organizations: The GLOBE study of 62 societies. Thousand Oaks: Sage. 
House, R.J./Javidan, M. (2004): Overview of GLOBE, in: House, R.J./Hanges, P.J./Javidan, M./Dorfman, P.W./Gupta, V. (eds.): Culture, leadership, and organizations: The GLOBE study of 62 societies. Thousand Oaks: Sage, 9-28.

House, R.J./Shamir, B. (1993): Toward the integration of transformational, charismatic and visionary theories of leadership, in: Chemers, M./Aydita, R. (eds.): Leadership theory and research: Perspectives and research directions. San Diego: Academic Press, 81-108.

Javidan, M./House, R.J./Dorfman, P.W. (2004): A nontechnical summary of GLOBE findings, in: House, R.J./Hanges, P.J./Javidan, M./Dorfman, P.W./Gupta, V. (eds.): Culture, leadership, and organizations: The GLOBE study of 62 societies. Thousand Oaks: Sage, 29-48.

Javidan, M./House, R.J./Dorfman, P.W./Hanges, P.J./Sully de Luque, M. (2006): Conceptualizing and measuring cultures and their consequences: A comparative review of GLOBE's and Hofstede’s approaches, in: Journal of International Business Studies, 37, 6, 897-914.

Keating, M.A./Martin, G.S./Szabo, E. (2002): Do managers and students share the same perceptions of societal culture?, in: International Journal of Intercultural Relations, 26, 6, 633-652.

Kluckhohn, F./Strodtbeck, F. (1961): Variations in value orientation. Evanston: Row, Peterson \& Company.

Kreitner, R. (1989): Management. Boston: Houghton Mifflin.

Lang, R./Alas, R./Alt, R./Catana, D./Hartz, R. (2005): Leadership in transformation - between local embeddedness and global challenges, in: Journal of Cross-Cultural Competence and Management, 4, 215-246.

Lang, R./Catana, A./Catana, D./Steyrer, J. (2008): Impacts of motives and leadership attributes of entrepreneurs and managers on followers' commitment in transforming countries - A comparison of Romania, East Germany and Austria, in: Jurczek, P./Niedobitek, M. (eds.): Europäische Forschungsperspektiven - Elemente einer Europawissenschaft. Berlin: Duncker \& Humblot, 109-135.

Leung, K./Bhagat, R.S./Buchan, N.R./Erez, M./Gibson, C.B. (2005): Culture and international business: Recent advances and their implications for future research, in: Journal of International Business Studies, 36, 4, 357-378.

Lewin, K./LIippit, R./White, R.K. (1939): Patterns of aggressive behavior in experimentally created social climates, in: Journal of Social Psychology, 10, 271-301.

Likert, R. (1961): New patterns of management. New York: McGraw-Hill.

Lindert, K. (1996): Führungskonzeptionen im Wandel: Eine interkulturelle und intertemporale Studie. Gemeinsamkeiten und Unterschiede west- und osteuropäischer Führungskräfte, in: Lang, R. (ed.): Wandel von Unternehmenskulturen in Ostdeutschland und Osteeuropa. München/Mering: Hampp, 91-106.

Lord, R.G./Maher, K.J. (1993): Leadership and information processing: Linking perceptions to performance. London: Routledge.

Maseland, R./van Hoorn, A. (2009): Explaining the negative correlation between values and practices: A note on the Hofstede-GLOBE debate, in: Journal of International Business Studies, 40, 3, 527-532.

Maseland, R./van Hoorn, A. (2010): Values and marginal preferences in international business, in: Journal of International Business Studies, 41, 8, 1325-1329.

McClelland, D.C. (1961): The archieving society. Princeton: Van Nostrand. 
McClelland, D.C. (1987): Human motivation. Cambridge: Cambridge University Press.

McCrae, R.R./Terracciano, A./Realo, A./Allik, J. (2008): Interpreting GLOBE societal practices scales, in: Journal of Cross-Cultural Psychology, 39, 6, 805-810.

McGregor, D. (1960): The human side of the enterprise. New York: McGraw-Hill.

McQuail, D. (2005): McQuail's mass communication theory (5 $5^{\text {th }}$ ed.). London et al.: Sage.

McSweeney, B. (2002): Hofstede's model of national cultural differences and their consequences: A triumph of faith - a failure of analysis, in: Human Relations, 55, 1, 89-118.

Mead, R. (1998): International management: Cross-cultural dimensions. Malden: Blackwell Publishers.

Merritt, A. (2000): Culture in the cockpit: Do Hofstede’s dimensions replicate?, in: Journal of CrossCultural Psychology, 31, 3, 283-301.

Mihelič, K.K./Lipičnik, B. (2010): Corporate managers and their potential younger successors: An examination of their values, in: Journal for East European Management Studies, 15, 4, 288311.

Mulder, M. (1977): The daily power game. Leydem: Martinus Nijhoff.

Northouse, P.G. (2004): Leadership: Theory and practice. Thousand Oaks: Sage.

Nunnally, J.C./Bernstein, I.H. (1994): Psychometric theory. New York: McGraw-Hill.

Parsons, T. (1949): Essays in sociological theory: Pure and applied. New York: Free Press.

Peterson, M.F./Hunt, J.G. (1997): Overview: International and cross-cultural leadership research (Part II), in: Leadership Quarterly, 8, 4, 339-342.

Pohlmann, M./Gergs, H.-J. (1996): Manageriale Eliten im Transformationsprozess, in: Pohlmann, M./Schmidt, R. (eds.): Management in der ostdeutschen Industrie. Opladen: Westdeutscher Verlag, 63-98.

Reddin, W. (1970): Managerial effectiveness. New York: McGraw-Hill.

Redfield, R. (1948): Introduction to Malinovski, B.: Magic, science, and religion. Boston: Beacon Press.

Sahgal, P./ Phatak, A. (2007): Transformational leaders: Their socialization, self-concept and shaping experiences, in: International Journal of Leadership Studies, 2, 3, 263-279.

Schein, E.H. (2010): Organizational culture and leadership ( $4^{\text {th }}$ ed.). New York: John Wiley \& Sons.

Schneider, C.S./Barsoux, J.-L. (2003): Managing across cultures. Harlow: FT Prentice Hall.

Schwartz, S.H. (1992): Universals in the content and structure of values: Theoretical advances and empirical tests in 20 countries, in: Zanna, M.P. (ed.): Advances in experimental social psychology (Vol. 25). New York: Academic Press, 1-65.

Schwartz, S.H. (1996): Value priorities and behavior: Applying a theory of integrated value systems, in: Seligman, C./Olson, J.M./Zanna, M.P. (eds.): The psychology of values: The Ontario Symposium (Vol. 8). Hillsdale, NJ: Erlbaum, 1-24.

Schwartz, S.H./Rubel, T. (2005): Sex differences in value priorities: Cross-cultural and multimethod studies, in: Journal of Personality and Social Psychology, 89, 6, 1010-1028.

Segall, M.H./Lonner, W.J./Berry, J.W. (1998): Cross-cultural psychology as a scholary discipline: On the flowering of culture in behavioral research, in: American Psychologist, 53, 10, 1101-1110. 
Smith, P.B. (2006): When elephants fight, the grass gets trampled: The GLOBE and Hofstede projects, in: Journal of International Business Studies, 37, 6, 915-921.

Steger, T./Winkler, I. (eds.) (2003): Leaders and leadership in Central and Eastern Europe. Special issue, in: Journal for East European Management Studies, 8. München/Mering: Hampp.

Steyrer, J./Hartz, R./Schiffinger, M. (2006): Leadership in transformation between local embeddedness and global challenges, in: Journal for East Europaean Management Studies, 11, 2, 113-139.

Szabo, E./Reber, G./Weibler, J./Brodbeck, F.C./Wunderer, R. (2001): Values and behavior orientation in leadership studies: Reflections based on findings in three German-speaking countries, in: Leadership Quarterly, 12, 2, 219-244.

Tannenbaum, R./Schmidt, W. (1958): How to choose a leadership pattern, in: Harvard Business Review, 36, March-April, 95-101.

Taras, V./Rowney, J./Steel, P. (2009): Half a century of measuring culture: Review of approaches, challenges, and limitations based on the analysis of 121 instruments for quantifying culture, in: Journal of International Management, 15, 4, 357-373.

Taras, V./Steel, P./Kirkman, B.L. (2010): Negative practice-value correlations in the GLOBE data: Unexpected findings, questionnaire limitations and research directions, in: Journal of International Business Studies, 41, 8, 1330-1338.

Triandis, H.C. (2004): The many dimensions of culture, in: Academy of Management Executive, 18, 1, 88-93.

Triandis, H.C./Bontempo, R./Betancourt, H./Bond, M./Leung, K./Brenes, A./Georgas, J./Hui, H./Marin, G./Setiadi, B./Sinha, J.B.P./Verma, J./Spangenberg, J./Tiouzard, H./de Montmollin, G. (1986): The measurement of the etic aspects of individualism and collectivism across cultures, in: Australian Journal of Psychology, 38, 3, 257-267.

Venaik, S./Brewer, P. (2010): Avoiding uncertainty in Hofstede and GLOBE, in: Journal of International Business Studies, 41, 8, 1294-1315.

Weaver, G.R./Treviño, L.K./Agle, B. (2005): “Somebody I look up to”: Ethical role models in organizations, in: Organizational Dynamics, 34, 4, 313-330.

Williams, R.M. (1979): Change and stability in values and value systems: A sociological perspective, in: Rokeach, M. (ed.): Understanding human values: Individual and societal. New York: Free Press, 15-46.

Williamson, D. (2002): Forward from a critique of Hofstede's model of national culture, in: Human Relations, 55, 11, 1373-1395. 